\title{
観光駐車場の将来計画に関する研究
}

一実計算例飞ついて—

正員毛利正光*

\section{STUDY ON THE FUTURE PLANNING OF SIGHT-SEEING PARKING SPACES}

\section{By Masamitsu Mōri, C.E. Member}

Synopsis: In this paper, the author has applied the fundamental theory, which was already described in Part 1 of the Study on the Future Planning of Sight-seeing Parking Spaces, to the planning in the City of Kyoto, then calculated the required spaces and presented the numerical examples.

要旨 本論文は，先飞镌光駐車場の将来計画々関する研究一理論の部一に陉いて述べた，基礎理論を京都市に おける計画と適用し，所要の容量を算定した計算例について述べたものである。

1. 駐車需要台数の週日変化に関する考察

1）実測値に基づく検定

I. 一方のランの数汇よる場合

\section{(a) 盛山観光駐車場}

i） 日曜日を $\mathrm{a}$ との他の週日をb とした場合：前論文 ${ }^{11}$ と示した資料基づいて，a が $13(=m) ， \mathrm{~b} か ゙ 77(=n)$ であるからこのような順列は $l ! / m ! n !=90 ! / 13 ! 77 !$ 通りそなる。そして 岋これだけの順列はすべて等しい確率で起こることになる。いま $\mathrm{a}, \mathrm{b}$ を大きさの順汇並べると

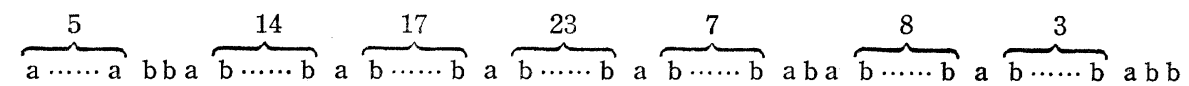
の配列となり, a のラン $r=9, \mathrm{~b}$ のラン $s=9$ となつているから式 (33) から,

$$
\begin{aligned}
& P_{r}(r)=\frac{12 !}{(r-1) !(13-r) !} \cdot \frac{78 !}{(78-r) ! r !} / \frac{90 !}{13 ! 77 !} \\
\therefore & P_{r}(r=9)=\frac{12 !}{8 ! 4 !} \cdot \frac{78 !}{69 ! 9 !} / 1.64339 \times 10^{15}=0.0548
\end{aligned}
$$

同様江

$$
P_{r}(s)=\frac{76 !}{(s-1) !(77--s) !} \cdot \frac{14 !}{(14-s) ! s !} / \frac{90 !}{77 ! 13 !}
$$

$$
\therefore P_{r}(s=9)=\frac{76 !}{8 ! 68 !} \cdot \frac{14 !}{5 ! 9 !} / 1.64339 \times 10^{15}=0.0231
$$

ii）土, 日曜日を a，その他の週日を b とした場合：交献 1) から $m=26, n=64$ で a, b の配列は，

$$
\begin{aligned}
& \overbrace{\mathrm{a} \cdots \cdots \mathrm{a}}^{6} \mathrm{babb} \text { a } \overbrace{\mathrm{b} \cdots \cdots \mathrm{b}}^{5} \mathrm{a} \overbrace{\mathrm{b} \cdots \cdots \mathrm{b}}^{5} \text { a a } \overbrace{\mathrm{b} \cdots \cdots \mathrm{b}}^{3} \mathrm{a} \overbrace{\mathrm{b} \cdots \cdots \mathrm{b}}^{12} \text { a b a } \overbrace{\mathrm{b} \cdots \cdots \mathrm{b}}^{3} \mathrm{a} \\
& \overbrace{\mathrm{b} \cdots \cdots \mathrm{b}}^{4} \mathrm{a} \overbrace{\mathrm{b} \cdots \cdots \mathrm{b}}^{10} \overbrace{\mathrm{a} \cdots \cdots \mathrm{a}}^{3} \overbrace{\mathrm{b} \cdots \cdots \mathrm{b}}^{7} \mathrm{a} \mathrm{b} \overbrace{\mathrm{a} \cdots \cdots \mathrm{a}}^{4} \overbrace{\mathrm{b} \cdots \cdots \mathrm{b}}^{5} \mathrm{a} \overbrace{\mathrm{b} \cdots \cdots \mathrm{b}}^{3} \text { a b a }
\end{aligned}
$$

となるから, $r=16, s=15$, 式 (33) から,

$P_{r}(r=16)=\frac{25 !}{15 ! 10 !} \cdot \frac{65 !}{49 ! 16 !} / \frac{90 !}{26 ! 64 !}=0.0938, P_{r}(s=15)=\frac{63 !}{14 ! 49 !} \cdot \frac{27 !}{12 ! 15 !} / \frac{90 !}{64 ! 26 !}=0.0287$

(b) 清水坂観光駐車場

i）日曜日を $\mathrm{a}$ ，その他の週日を bとした場合：文献 2) 飞示した資料沉より $m=13, n=77, \mathrm{a}, \mathrm{b}$ のランは $r=12, s=12$ となるから, 式 (33) から, 
$P_{r}(r=12)=\frac{12 !}{11 ! 1 !} \cdot \frac{78 !}{66 ! 12 !} / \frac{90 !}{13 ! 77 !}=0.318, P_{r}(s=12)=\frac{76 !}{11 ! 65 !} \cdot \frac{14 !}{2 ! 12 !} / \frac{90 !}{77 ! 13 !}=0.318$

ii）土，日曜日を $\mathrm{a} ，$ その他の週日をbとした場合：交献 2) から $m=26, n=64, \mathrm{a}, \mathrm{b}$ のランは $r=21$, $s=21$, となるから, 式 (33) から,

$\operatorname{Pr}(r=21)=\frac{25 !}{20 ! 5 !} \cdot \frac{65 !}{44 ! 21 !} / \frac{90 !}{26 ! 64 !}=0.143, P_{r}(s=21)=\frac{63 !}{20 ! 43 !} \cdot \frac{27 !}{6 ! 21 !} / \frac{90 !}{64 ! 26 !}=0.177$

以上の計算結果を示すと 表一 1 のごとくである。

表一1 一方のランによる検定

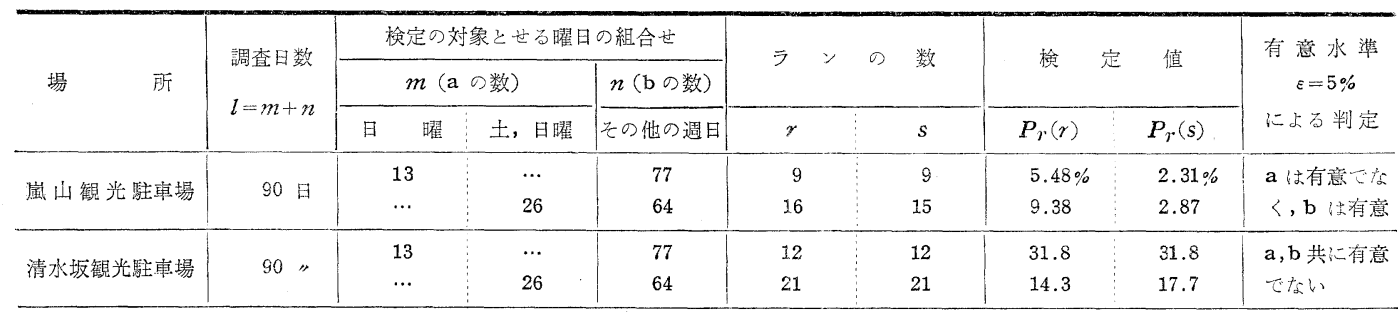

すなわち有意水準 $\varepsilon=0.05$ で,垌山に和ける土睢, 日曜をのぞいた他の週日のランの数が少なすぎるということが できる。したがつてその配列は無規則でないととになる。清水坂に执いてはいずれも無規則であると結論される。 もし $\varepsilon=10 \%$ とすれば，咸山ではいずれる $P_{r}(r)<0.10$ となるから，90\%の信頼度でいずれの配列も不規則で ないとい党る。すなわち土，日曜は別汉別して考觉るべきだと結論され，清水坂では，この場合でる無規則性 の仮定が成立することになる。

II ランの総数による場合

(c) 循山観光駐車場

i）日曜日を $\mathrm{a}$ ，その他の週日をbとした場合：(a) の i) で述べたようと a のラン $r=9, b$ のラン $s=9$ であるから， $u=9+9=18$ で $m=13, n=77, u$ は偶数であるから式 (34) で $k=9$ として，

$$
P_{r}(u=18)=2 \cdot \frac{12 !}{8 ! 4 !} \cdot \frac{76 !}{8 ! 68 !} / \frac{90 !}{13 ! 77 !}=0.0114
$$

ii）土，日曜日を $\mathrm{a} ，$ その他の週日をbとした場合： $u=r+s=16+15=31, m=26, n=64, u$ は奇数であ るから式 (35) で $k=15$ となるから，

(d) 清水坂観光駐車場

$$
P_{r}(u=31)=\frac{60 \cdot 25 ! 63 !}{11 ! 49 ! 15 ! 14 !} / \frac{90 !}{26 ! 64 !}=0.0296
$$

i）日曜日を $\mathrm{a}$ ，その他の週日をbとした場合：(b) の i) で述べたととから， $u=r+s=12+12=24, m=$ 13, $n=77$, 乙たがつて式 (34) 飞招いて $k=12$ として,

$$
P_{r}(u=24)=2 \cdot \frac{12 !}{11 ! 1 !} \cdot \frac{76 !}{11 ! 65 !} / \frac{90 !}{13 ! 77 !}=0.0839
$$

ii）土，日曜日を $\mathrm{a}$ ，その他の週日をbとした場合： $u=r+s=21+21=42, m=26, n=64$ ， 党飞式（34） で $k=21$ として,

$$
P_{r}(u=42)=2 \cdot \frac{25 !}{20 ! 5 !} \cdot \frac{63 !}{20 ! 43 !} / \frac{90 !}{26 ! 64 !}=0.0638
$$

\begin{tabular}{|c|c|c|c|c|c|c|c|}
\hline \multirow{3}{*}{ 場 } & \multirow{3}{*}{$\begin{array}{l}\text { 調查日 数 } \\
\quad l=m+n\end{array}$} & \multicolumn{3}{|c|}{ 検定の対象とせる曜日の組合せ } & \multirow{3}{*}{$\begin{array}{c}\text { ランの 総数 } \\
u=r+s\end{array}$} & \multirow{3}{*}{$\begin{array}{c}\text { 検 定 值 } \\
P_{r}(u)\end{array}$} & \multirow{3}{*}{$\begin{array}{l}\text { 有 意 水 準 } \\
\qquad=5 \% \\
\qquad よ る \text { 判定 }\end{array}$} \\
\hline & & \multicolumn{2}{|c|}{$m$} & \multirow{2}{*}{$\frac{n}{\text { その他の週日 }}$} & & & \\
\hline & & 日曜 & 土, 日曜 & & & & \\
\hline 嵐山観光駐車場 & 90 日 & $\begin{array}{l}13 \\
\ldots\end{array}$ & $\begin{array}{l}\cdots \\
26\end{array}$ & $\begin{array}{l}77 \\
64\end{array}$ & $\begin{array}{l}1.8 \\
31\end{array}$ & $\begin{array}{l}1.14 \% \\
2.96\end{array}$ & いザれも有意 \\
\hline 清水坂観光駐車場 & $90 "$ & $\begin{array}{l}13 \\
\ldots\end{array}$ & $\begin{array}{l}\cdots \\
26\end{array}$ & $\begin{array}{l}77 \\
64\end{array}$ & $\begin{array}{l}24 \\
42\end{array}$ & $\begin{array}{l}8.39 \\
6.38\end{array}$ & 共に有意でない \\
\hline
\end{tabular}

この場合の計算結果は 表一2 のごとくなる。

表一2 ランの総数による検定

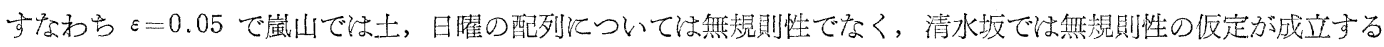

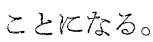


以上の表一 1,2 そ示すととから, 駐車需要の週日変 化について考察する場合, 嵲山については土曜, 日㬦 は別個济考るべきであり，清水坂では週日による変 化特別々考虑する必要がないとい兄ることになる。

\section{2. 駐車需要台数の時間変化並びにその将来值}

風山和上び清水师観光駐車場飞扔ける昭和 29〜31 年の 3 年間の駐車台数は文献 1) 特よび文献 2) 飞示 した通りであるが，この1日当りの駐龺台数を大きさ の順に並べ，これを図示すると図一1のごとくなる。 乙かして先汇駐車需要の週日変化汇関する考察湉い て述ベたごとく, 峲山観光駐車場に抒いては, 土睢, 日㺟は乞の他の週日とは別個の現象と乙て考克, 清水 坂観光駐車場では週日による変化は特別汇考慮する必 要はないとの結論学得た。したがつてつぎのように考 えることにしたい。

\section{(a) 嵐山観光駐車場}

風山に和いては駐車需要の集中すると考光られる土 濯,日曜㣙いて,その時間変化を大きさの順良つて 第6 位まで文献1)から拾つてみると表一-3のようであ る。しかして 1 日(午前 8 時から午後 6 時末で)の駐車 台数を $100 \%$ とした場合の各 1 時間当りの駐車台数の 平均の比率は表の平均の欄示した値のようになる。

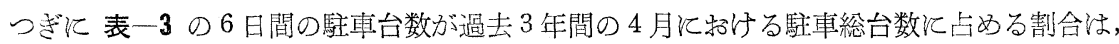

$$
1916 \div(3558+3925+4646)=0.1385
$$

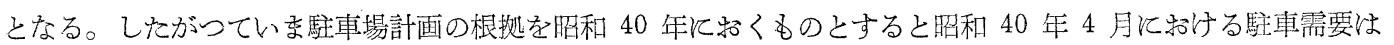
季節変動量の推計文献 3) 飞述べてように 6855 台であるから，このときの1日当りの駐車需要は，

$$
6855 \text { 台 } \times 0.1385 \div(6 / 3) \div 475 \text { 台 }
$$

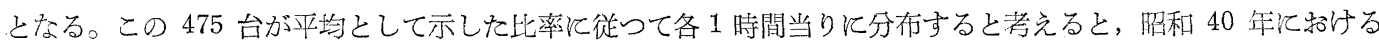
各 1 時間当りの駐車需要の状洸は 表一 3 の最下糷に示す値となる。

\begin{tabular}{|c|c|c|c|c|c|c|c|c|c|c|c|c|c|}
\hline \multirow{2}{*}{\multicolumn{2}{|c|}{ 大きさの順 }} & \multicolumn{5}{|c|}{ 時 } & \multicolumn{5}{|c|}{ 間 } & \multirow{2}{*}{ 合 計 } & \multirow{2}{*}{ 俑 } \\
\hline & & $8 \sim 9$ & $9 \sim 10$ & $10 \sim 11$ & $11 \sim 12$ & $12 \sim 1$ & $1 \sim 2$ & $2 \sim 3$ & $3 \sim 4$ & $4 \sim 5$ & $5 \sim 6$ & & \\
\hline \multicolumn{2}{|c|}{1} & $\begin{array}{l}2 \\
0.67\end{array}$ & $\begin{array}{l}8 \\
2.42\end{array}$ & $\begin{array}{l}22 \\
6.67\end{array}$ & $\begin{array}{l}52 \\
15.76\end{array}$ & $\begin{array}{l}63 \\
19.09\end{array}$ & $\begin{array}{l}64 \\
19.39\end{array}$ & $\begin{array}{l}77 \\
23.33\end{array}$ & $\begin{array}{l}22 \\
6.67\end{array}$ & $\begin{array}{l}15 \\
4.55\end{array}$ & $\begin{array}{l}5 \\
1.52\end{array}$ & $\begin{array}{l}330 \text { 台 } \\
100 \%\end{array}$ & 昭. 29.4 .4 \\
\hline \multicolumn{2}{|c|}{2} & $\begin{array}{l}6 \\
1.97\end{array}$ & $\begin{array}{l}9 \\
2.95\end{array}$ & $\begin{array}{l}19 \\
6.23\end{array}$ & $\begin{array}{l}43 \\
14.10\end{array}$ & $\begin{array}{l}54 \\
17.70\end{array}$ & $\begin{array}{l}85 \\
27.87\end{array}$ & $\begin{array}{l}39 \\
12.79\end{array}$ & $\begin{array}{l}33 \\
10.82\end{array}$ & $\begin{array}{l}12 \\
3.93\end{array}$ & $\begin{array}{l}5 \\
1.64\end{array}$ & $\begin{array}{l}305 \\
100\end{array}$ & 31.4 .15 \\
\hline \multicolumn{2}{|c|}{3} & $\begin{array}{l}5 \\
1: 74\end{array}$ & $\begin{array}{l}11 \\
3.83\end{array}$ & $\begin{array}{l}43 \\
14.98\end{array}$ & $\begin{array}{l}70 \\
24.39\end{array}$ & $\begin{array}{l}48 \\
16.72\end{array}$ & $\begin{array}{l}30 \\
10.45\end{array}$ & $\begin{array}{l}36 \\
12.54\end{array}$ & $\begin{array}{l}24 \\
8.36\end{array}$ & $\begin{array}{l}19 \\
6.62\end{array}$ & $\begin{array}{l}1 \\
0.35\end{array}$ & $\begin{array}{l}287 \\
100\end{array}$ & 29.4 .11 \\
\hline \multicolumn{2}{|c|}{4} & $\begin{array}{l}12 \\
4.23\end{array}$ & $\begin{array}{l}17 \\
5.99\end{array}$ & $\begin{array}{l}28 \\
9.86\end{array}$ & $\begin{array}{l}35 \\
12.32\end{array}$ & $\begin{array}{l}44 \\
15.49\end{array}$ & $\begin{array}{l}54 \\
19.01\end{array}$ & $\begin{array}{l}41 \\
14.44\end{array}$ & $\begin{array}{l}31 \\
10.92\end{array}$ & $\begin{array}{l}20 \\
7.04\end{array}$ & $\begin{array}{l}2 \\
0.70\end{array}$ & $\begin{array}{l}284 \\
100\end{array}$ & 30.4 .10 \\
\hline \multicolumn{2}{|c|}{5} & - & $\begin{array}{l}9 \\
3.44\end{array}$ & $\begin{array}{l}15 \\
5.73\end{array}$ & $\begin{array}{l}45 \\
17.18\end{array}$ & $\begin{array}{l}74 \\
28.24\end{array}$ & $\begin{array}{l}57 \\
21.76\end{array}$ & $\begin{array}{l}27 \\
10.31\end{array}$ & $\begin{array}{l}16 \\
6.11\end{array}$ & $\begin{array}{l}12 \\
4.58\end{array}$ & $\begin{array}{l}7 \\
2.67\end{array}$ & $\begin{array}{l}262 \\
100\end{array}$ & 30.4 .3 \\
\hline \multicolumn{2}{|c|}{6} & $\begin{array}{l}18 \\
8.45\end{array}$ & $\begin{array}{l}4 \\
1.88\end{array}$ & $\begin{array}{l}6 \\
2.82\end{array}$ & $\begin{array}{l}41 \\
19.25\end{array}$ & $\begin{array}{l}47 \\
22.07\end{array}$ & $\begin{array}{l}35 \\
16.43\end{array}$ & $\begin{array}{l}14 \\
6.57\end{array}$ & $\begin{array}{l}20 \\
9.39\end{array}$ & $\begin{array}{l}15 \\
7.04\end{array}$ & $\begin{array}{l}13 \\
6.10\end{array}$ & $\begin{array}{l}213 \\
100\end{array}$ & 31.4 .14 \\
\hline 合 & 訫 & $\begin{array}{l}43 \\
16.66\end{array}$ & $\begin{array}{l}58 \\
20.51\end{array}$ & $\begin{array}{l}133 \\
46.29\end{array}$ & $\begin{array}{l}286 \\
103.00\end{array}$ & $\begin{array}{l}330 \\
119.31\end{array}$ & $\begin{array}{l}325 \\
114.91\end{array}$ & $\begin{array}{l}234 \\
79.98\end{array}$ & $\begin{array}{l}146 \\
52.27\end{array}$ & $\begin{array}{l}93 \\
33.76\end{array}$ & $\begin{array}{l}33 \\
12.98\end{array}$ & 1916 台 & . \\
\hline 平 & 均 & 2.87 & 3.42 & 7.72 & 17.17 & 19.88 & 19.15 & 13.33 & 8.74 & 5.63 & 2.61 & $100 \%$ & \\
\hline 昭和 & :の值 & 13.2 & 16.2 & 36.7 & 81.6 & 94.4 & 91.0 & 63.3 & 41.4 & 26.7 & 10.3 & 475 台 & 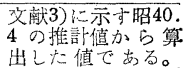 \\
\hline
\end{tabular}

\section{表一3 嵐山観光駐車晹における駐車需要の時間変化}


(b) 清水坂観光駐車場

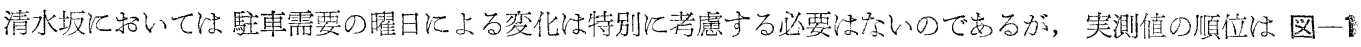
飞示すごとくで, この内最初の 2 つ 3 年間飞 2 回生起して異常現象と考克られるから, 経済的設計を行う上に, これを計画資料から除外し，第 3 位から 6 つをると表一4のごとくなる。すなわちこの6日間の資料を時間 変化算定上の基礎として，(a) に捛いて述べたと同じように各時間当りの駐車台数の比率を求めると，表一4の 平均のごとくでめる。

昭和 40 年 4 月の駐車需要を計画の根拠とすると,このときの一日当りの駐車需要ほつぎのよう汇阡算される。 $2032 \div(7688+8177+8472)=0.0835$

$\therefore 11481$ 台 $\times 0.0835 \div 2 \div 480$ 台

従つてこの場合の各 1 時間当りの駐車需要岕 表一 4 の最下闌注示すごとくなる。

以上駐車場計画江必要な駐車需要の時間 強度を算定することができた。したがつて各駐車場沉和ける車の平均 駐車時間を実測から決めれば所要の駐車場容量の算定ができることになる。

\section{表一4＼cjkstart清水坂観光駐車場における駐車需要の時間変化}

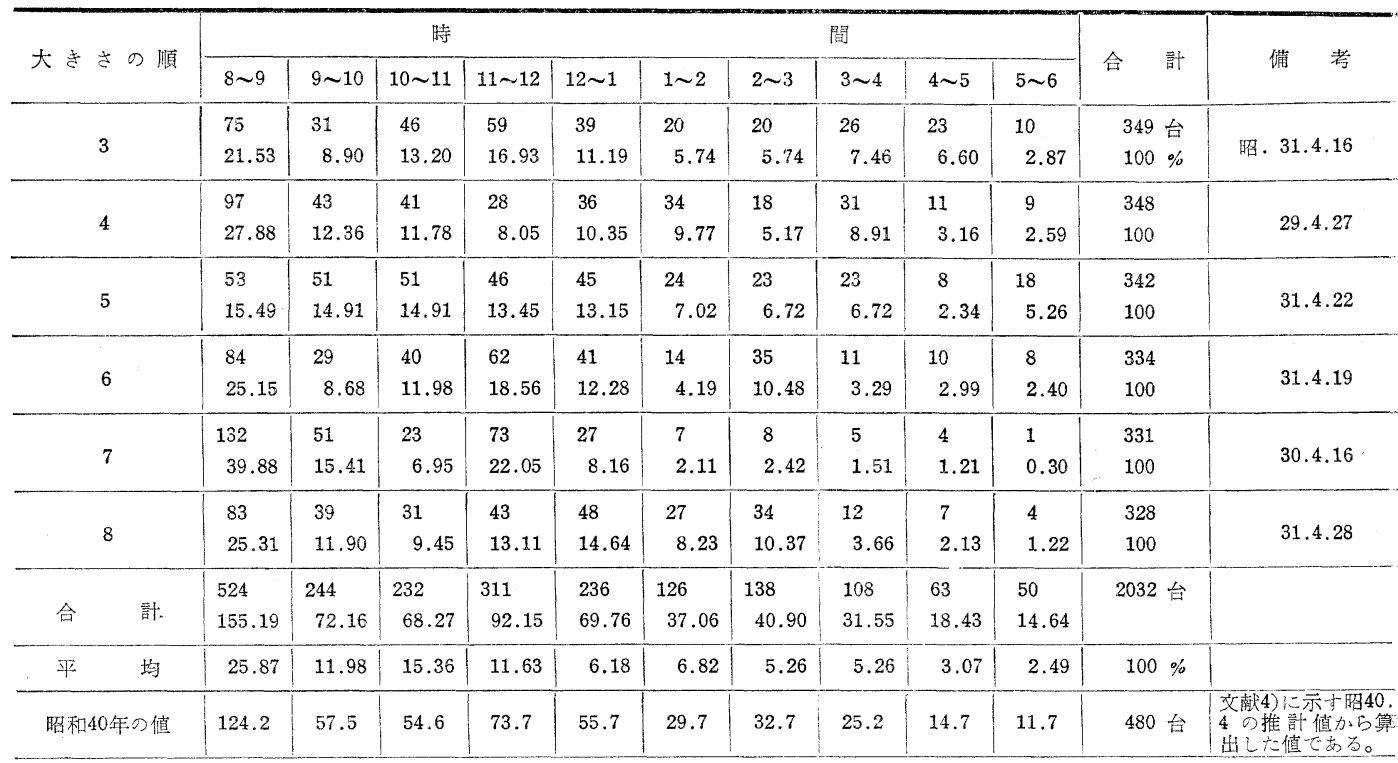

\section{3. 駐車実態調查および平均駐車時間}

駐車場容量算定に必要な平均駐車時間を実測するため 所要の実態調査を行い，駐車の分布状況を求めて結果， 嵐山に括いては平均駐車時間 71.6 分，清水坂では 55.5 分の実測值を得て。各駐車場に括ける駐車の分布の模 㥞は 表一5，6 亿示すどとくであつた。

表一5 駐車の分布および駐車時間

調查場所嵐山駐車場昭和 31 年 10 月 14 日（日）

平均駐車時間 71.6 分

\begin{tabular}{|c|c|c|c|c|c|c|c|c|c|c|c|}
\hline \multirow{2}{*}{ 時間区分 } & \multicolumn{4}{|c|}{ 駐 } & \multicolumn{5}{|c|}{ 間 （分） } & \multirow{2}{*}{ 計 } & \multirow{2}{*}{$\%$} \\
\hline & 30以下 & $30 \sim 60$ & $60 \sim 90$ & $90 \sim 120$ & $120 \sim 150$ & $150 \sim 180$ & $180 \sim 210$ & $210 \sim 240$ & 240 以上 & & \\
\hline $9.00 \sim 10.00$ & 3 & 11 & & & & 1 & & \multirow{8}{*}{1} & \multirow[t]{2}{*}{4} & 15 & 9.5 \\
\hline $10.00 \sim 11.00$ & 5 & 10 & 2 & 6 & 1 & 1 & 1 & & & 30 & 19.0 \\
\hline $11.00 \sim 12.00$ & \multirow[t]{4}{*}{9} & 7 & 12 & & 1 & & & & \multirow[t]{6}{*}{ (4) } & 30 & 19.0 \\
\hline $12.00 \sim 13.00$ & & 5 & 18 & 6 & 2 & 1 & & & & $\begin{array}{l}(1) \\
32\end{array}$ & 20.9 \\
\hline $13.00 \sim 14.00$ & & 3 & 9 & & 1 & 1 & & & & $\begin{array}{l}32 \\
14\end{array}$ & 8.8 \\
\hline $14.00 \sim 15.00$ & & 6 & 3 & 2 & & & & & & 11 & 7.0 \\
\hline $15.00 \sim 16.00$ & \multirow{2}{*}{$\begin{array}{c}4 \\
(2) \\
5\end{array}$} & \multirow{2}{*}{$\begin{array}{c}7 \\
(1) \\
1\end{array}$} & \multirow[t]{2}{*}{4} & \multirow[t]{2}{*}{1} & & & & & & 16 & 10.1 \\
\hline $16.00 \sim 17.00$ & & & & & & & & & & $\begin{array}{c}(3) \\
6\end{array}$ & 5.7 \\
\hline 計 & $\begin{array}{l}(2) \\
26\end{array}$ & $\begin{array}{l}(1) \\
50\end{array}$ & 48 & 15 & 5 & 4 & 1 & 1 & $\begin{array}{c}(1) \\
4\end{array}$ & $\begin{array}{c}(4) \\
154\end{array}$ & 100.0 \\
\hline 相対度数\% & 17.7 & 32.3 & 30.4 & 9.4 & 3.2 & 2.6 & 0.6 & 0.6 & 3.2 & 100.0 & \\
\hline 累積度 数\% & 17.7 & 50.0 & 80.4 & 89.8 & 93.0 & 95.6 & 96.2 & 96.8 & 100.0 & & \\
\hline
\end{tabular}

註（）内の数字は $17.00 \mathrm{hr}$ にな㧍駐車継続中の台数を示す。 


\section{表一6 駐車の分布および駐車時間}

調查場所 清水坂駐車場

昭和 31 年 10 月 11 日（木）

平均駐車時間 55.5 分

\begin{tabular}{|c|c|c|c|c|c|c|c|c|c|c|c|c|}
\hline \multirow{2}{*}{ 時間区分 } & \multicolumn{3}{|r|}{ 毁 } & \multicolumn{2}{|l|}{ 車 } & 時 & 間 & \multicolumn{3}{|l|}{ （分） } & \multirow{2}{*}{ 誩 } & \multirow{2}{*}{$\%$} \\
\hline & 10以下 & $10 \sim 20$ & $20 \sim 30$ & $30 \sim 40$ & $40 \sim 50$ & $50 \sim 60$ & $60 \sim 70$ & $70 \sim 80$ & $80 \sim 90$ & $90 \sim 100$ & & \\
\hline $7.00 \sim 8.00$ & \multirow[b]{9}{*}{ (1) } & \multirow{9}{*}{1} & \multirow{7}{*}{1} & 6 & 8 & 2 & & \multirow{4}{*}{2} & \multirow[b]{4}{*}{9} & \multirow{6}{*}{6} & 16 & 7.5 \\
\hline $8.00 \sim 9.00$ & & & & 10 & 5 & 7 & 1 & & & & 23 & 10.8 \\
\hline $9.00 \sim 10.00$ & & & & 3 & 16 & 7 & 8 & & & & 36 & 16.8 \\
\hline $10.00 \sim 11.00$ & & & & 8 & 6 & 2 & 1 & & & & 27 & 12.6 \\
\hline $11.00 \sim 12.00$ & & & & 6 & 2 & 3 & 14 & 4 & 8 & & 43 & 2.01 \\
\hline $12.00 \sim 13.00$ & & & & & & 2 & 2 & 8 & 3 & & 21 & 9.8 \\
\hline $13.00 \sim 14.00$ & & & & & 12 & & & & 2 & & 15 & 7.0 \\
\hline $14.00 \sim 15.00$ & & & 4 & & 7 & 3 & 2 & & & & 16 & 7.5 \\
\hline $15.00 \sim 16.00$ & & & (2) & $\begin{array}{c}(4) \\
9 \\
\end{array}$ & 1 & & & & & & $\begin{array}{l}(7) \\
10\end{array}$ & 7.9 \\
\hline 竐 & $\begin{array}{c}(1) \\
1\end{array}$ & 1 & $\begin{array}{c}(2) \\
5\end{array}$ & $\begin{array}{l}(4) \\
42 \\
\end{array}$ & 57 & 26 & 28 & 14 & 22 & 11 & $\begin{array}{c}(7) \\
207\end{array}$ & 100.0 \\
\hline 相対度 数\% & 0.9 & 0.5 & 3.3 & 21.5 & 26.6 & 12.2 & 13.1 & 6.5 & 10.3 & 5.1 & 100.0 & \\
\hline 累積度数\% & 0.9 & 1.4 & 4.7 & 26.2 & 52.8 & 65.0 & 78.1 & 84.6 & 94.9 & 100.0 & & \\
\hline
\end{tabular}

註（）内の数字は $16.00 \mathrm{hr}$ になお駐車継続中の台数を示す。

\section{4. 駐車場における車の累加状況之所要容量の算定}

上述べた基礎的研究と実測結果から 駐車場容量算定飞必要な㓪車需要の強度と, 平均駐車時間を明らか沉す ることができた。したがつていま基整理論5 と扔いて述べたごとく駐車需要生起の確率がポアソン分布に従い，平 均駐車時間が指数関数汇従うものと考觉ると所要容量の算定を行うことができることになる。しかしてこの場合 より合理的な算定方法として, われわれは時間別駐車需要强度を算定しているから, さき飞駐車場計画運営に関 する基礎的考察に招いて述べたごとく ${ }^{6\rangle}$, 駐車台数の分布の平均值は次式で計算される。

$$
E(t)=\frac{m}{l}\left(1-e^{-l t}\right)+i e^{-l t}
$$

この式の第 1 項は車両の入量の強度ととの継続時間関係し, 第 2 項は初期条件に関係する值である。乙かし て観光駐車場の特性として平均駐車時間は, 時間沉かからず一定の平均值をるつと考兄てよいから，この場合 その逆数 $l$ は定の常数であるとして次のごとく車の累加状況を算出することができる。

\section{(a) 風山観光駐車場}

駐車需要の強度はさきに述べたごとく昭和 40 年を計画の基礎として 表一7 の駐車需要の值として示すような 時間別強度を得ている。したがつて表江示す入量の強度の継続時間が 1 時間であるとして, 式 (1) の第 1 項の 值を計算したものが表の時間別累加台数の欄の各行の最初の值である。すなわち各 1 時間中に発生した駐車需要 のうち，各時間の終りと駐車継続中の車として分布すると考光られる台数であつて，これらの台数は第 1 時間目 以後江式 (1) の第 2 項従つて初期条件 $i$ となつて駐車分布することとなる。この值が各行の第 2 番目以下に 示す值である。乙たがつてこれらの值を時間別に集計すれば，それぞれの時間の終りと累加する車の台数を与兄

\section{表一1 時間別駐車需要強度と累加台数}

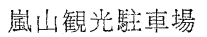

平均駐車時間 $1 / l=1.193$ 時間

\begin{tabular}{|c|c|c|c|c|c|c|c|c|c|c|c|}
\hline 時 & 間 & $\stackrel{1}{8 \sim 9}$ & $\stackrel{2}{9 \sim 10}$ & $\stackrel{3}{10 \sim 11}$ & $\stackrel{4}{11} \sim 12$ & $\stackrel{5}{12 \sim 1}$ & $\stackrel{6}{1 \sim 2}$ & $2 \stackrel{7}{\sim} 3$ & ${ }_{3 \sim 4}^{8}$ & $\stackrel{9}{4} 5$ & $\begin{array}{c}10 \\
5 \sim 6\end{array}$ \\
\hline \multicolumn{2}{|c|}{ 駐車需要（台/時） } & 13.2 & 16.2 & 36.7 & 81.6 & 94.4 & 91.0 & 63.3 & 41.4 & 26.7 & 10.3 \\
\hline $\begin{array}{l}\text { 時 } \\
\text { 間 } \\
\text { 別 } \\
\text { 累 } \\
\text { 加 } \\
\text { 台 } \\
\text { 数 }\end{array}$ & $\begin{array}{r}1 \\
2 \\
3 \\
4 \\
5 \\
6 \\
7 \\
8 \\
9 \\
10 \\
\end{array}$ & 8.9 & $\begin{array}{r}3.9 \\
10.9\end{array}$ & $\begin{array}{r}1.7 \\
4.7 \\
24.8\end{array}$ & $\begin{array}{r}0.7 \\
2.0 \\
10.7 \\
55.2\end{array}$ & $\begin{array}{r}0.3 \\
0.9 \\
4.6 \\
23.9 \\
63.8\end{array}$ & $\begin{array}{r}0.1 \\
0.4 \\
2.0 \\
10.3 \\
27.6 \\
61.6\end{array}$ & $\begin{array}{r}0.1 \\
0.2 \\
0.9 \\
4.5 \\
11.9 \\
26.6 \\
42.8\end{array}$ & $\begin{array}{r}0.1 \\
0.4 \\
1.9 \\
5.2 \\
11.5 \\
18.5 \\
28.0\end{array}$ & $\begin{array}{r}0.2 \\
0.8 \\
2.2 \\
5.0 \\
8.0 \\
12.1 \\
18.1\end{array}$ & $\begin{array}{l}0.1 \\
0.4 \\
1.0 \\
2.2 \\
3.5 \\
5.2 \\
7.8 \\
7.0 \\
\end{array}$ \\
\hline \multicolumn{2}{|c|}{ 累加台数の合計 } & 8.9 & 14.8 & 31.2 & 68.6 & 93.5 & 102.0 & 87.0 & 65.6 & 46.4 & 27.0 \\
\hline \multicolumn{2}{|c|}{$m / l$} & 15.7 & 19.3 & 43.8 & 97.3 & 112.6 & 108.6 & 75.5 & 49.4 & 31.9 & 12.3 \\
\hline
\end{tabular}


てくれることになる。すなわち表の合計欄に示す值である。これ 図一2 駐車台数累加状況 らの時間別累加台数の模様を図《示すと図一2 のようで, 嵐山に 怙いては，午後 1 時〜 2 時何駐車台数法最高となる。すなわちこ れらの車を全部取容するためには少なくとも 102 台以上の容量の 駐車場を必要とするわけで, これ《適当な駐車不能の生ずる確染 を考慮 ${ }^{7,8)}$ 乙て所要の計画を行うことができる。

(b) 清水坂観光駐車場

(a) そ述べたと同じようにして, 昭和 40 年に和ける駐車需要 と，車の累加台数を計算すると表一B 示すようとなる。これ を図示すると図一2 のようである。

この場合駐車台数のピークは午前 8 時〜 9時注ると考光られ， ついで第 2 のピークが正午頃にあり, 以下時刻とともに駐車台数 の分布は減少して行くことになる。乙たがつて 8 時以前と駐車需 要がないるのとすれ视，所要容量は76 台分であることになるが,

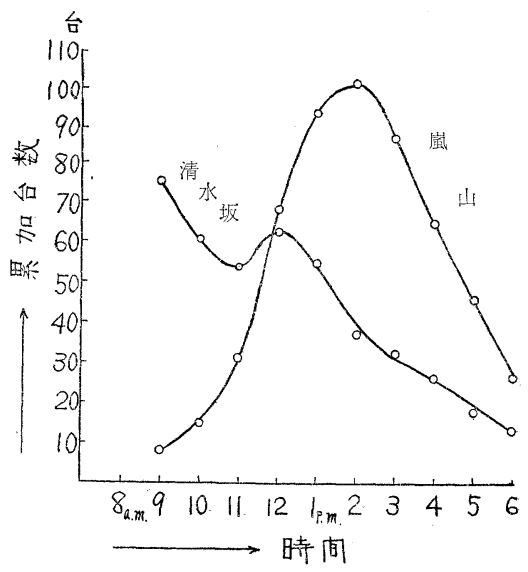

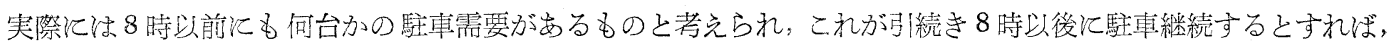
その必要量だけ加算しなければならない。最終的な容量算定のためには 8 時以前の駐車の実態を調查する必要が あるものと考光られる。

\section{表-8 時間別駐車需要強度と累加台数}

清水坂観光駐重場

平均駐車特間 $1 / l=0.925$ 時間

\begin{tabular}{|c|c|c|c|c|c|c|c|c|c|c|c|}
\hline 時 & 間 & $\stackrel{1}{8 \sim 9}$ & $\stackrel{2}{9 \sim 10}$ & ${ }_{10}^{3} \sim 11$ & $11 \stackrel{4}{\sim} 12$ & $\begin{array}{c}5 \\
12 \sim 1\end{array}$ & $\stackrel{6}{1 \sim 2}$ & $\stackrel{7}{2 \sim 3}$ & $\stackrel{8}{3 \sim 4}$ & $\stackrel{9}{4 \sim 5}$ & $\begin{array}{c}10 \\
5 \sim 6\end{array}$ \\
\hline \multicolumn{2}{|c|}{ 駐車需要（台/時） } & 124.2 & 57.5 & 54.6 & 73.7 & 55.7 & 29.7 & 32.7 & 25.2 & 14.7 & 11.7 \\
\hline \multirow{10}{*}{$\begin{array}{l}\text { 時 } \\
\text { 間 } \\
\text { 別 } \\
\text { 累 } \\
\text { 加 } \\
\text { 台 } \\
\text { 数 }\end{array}$} & 1 & 75.9 & 25.8 & 8.7 & 3.0 & 1.0 & 0.4 & 0.1 & & & \\
\hline & 2 & & 35.1 & 11.9 & 4.0 & 1.4 & 0.5 & 0.2 & 0.1 & & \\
\hline & 3 & & & 33.4 & 11.3 & 3.8 & 1.3 & 0.5 & 0.2 & 0.1 & \\
\hline & 4 & & & & 45.1 & 15.3 & 5.2 & 1.8 & 0.6 & 0.2 & 0.1 \\
\hline & 5 & & & & & 34.0 & 11.5 & 3.9 & 1.3 & 0.4 & 0.2 \\
\hline & 6 & & & & & & 18.2 & 6.2 & 2.1 & 0.7 & 0.2 \\
\hline & 7 & & & & & & & 20.0 & 6.8 & 2.3 & 0.8 \\
\hline & 8 & & & & & & & & 15.4 & 5.2 & 1.8 \\
\hline & 9 & & & & & & & & & 9.0 & 3.1 \\
\hline & 10 & & & & & & & & & & 7.1 \\
\hline \multicolumn{2}{|c|}{ 累加台数の合計 } & 75.9 & 60.9 & 54.0 & 63.4 & 55.5 & 37.1 & 32.7 & 26.5 & 17.8 & 13.3 \\
\hline \multicolumn{2}{|c|}{$m / l$} & 114.9 & 53.2 & 50.5 & 68.2 & 51.5 & 27.5 & 30.2 & 23.3 & 13.6 & 10.8 \\
\hline
\end{tabular}

\section{5. むすび}

以上京都に括ける代表的な観光対象である颳山ならびに清水坂について将来の駐車需要の推計の方法と時間 別駐車需要強度の值を示し, 実测による平均駐車時間とからそれぞれの場所に括ける車の累加状況を計算し, 必 要とされる駐車場容量決定の方法を示したるのであるが，累加台数の計算に当つては，すでに示したように時間 ととも変化する車の入量の強度を用いるのが実際上合理的である。しかしながらこの計算はかなり厄介であつ て, 式 (1) で示される平均駐車台数 $E(t)$ はすで飞基礎的考察で述べたごとく ${ }^{5), 6)} t \rightarrow \infty$ のとき $m / l$ にて計 算され，実用上 $t$ が $4 \sim 5$ 時間以上，すなわち同じ平均值を持つ駐車需要が 4 時間くらい継続するときには $E(t)$ $\doteqdot m / l$ として計算される*。てがつて計算と用いた各時閒別駐車需要の強度がかなりの時間継続するものと考兄 て近似的に $m / l$ にて計算して平均駐車台数も表-7, 表一8 亿示した。これらの值も容量決定上参考とせられるべ き值である。

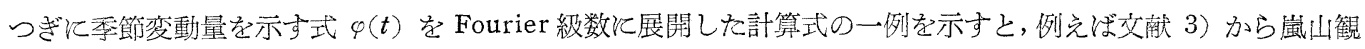
光駐車場化対しては

*乙れは $E(t)$ 式中の $e^{-l t}$ の收斂の状態によるるのであつて, $l$ が大すなわち平均駐車時間の短い場所では $t \fallingdotseq 3$ 時間程度で $E(t) \fallingdotseq m / l$ となる。 


$$
\begin{aligned}
\varphi(t) & \fallingdotseq\left(-717.2 \cos \frac{\pi}{6} t-320.0 \cos \frac{\pi}{3} t+8.4 \cos \frac{\pi}{2} t-405.3 \cos \frac{2}{3} \pi t\right. \\
& \left.-27.8 \cos \frac{5}{6} \pi t+7.3 \cos \pi t\right) \\
& +\left(622.0 \sin \frac{\pi}{6} t-1426.2 \sin \frac{\pi}{3} t+245.1 \sin \frac{\pi}{2} t+14.2 \frac{2}{3} \pi t-1.9 \sin \frac{5}{6} \pi t\right)
\end{aligned}
$$

となる。

また循環的な不規則変動を示す式 $\varepsilon(t)$ の值は，われわれはすで長期的变動と季節的変動を算出しているか ら，原時系列からとれらを徐去することにより求めることができるが，実際に数值計算を行うてめには相当長期 間の観測值を必要とするから 観測資料が整備せられれば改めて計算してみることとしたい。乙かし実用上は極め て小さい值となるから省略してる差支えないと考觉られる。

また駐車場の容量を算定するに当つて個々の車は独立に行動するものとして計算したが，これを㛜密に考える と観光バスなどの集団については，何台かの車がグループを形成して行動することがあるから駐車不能の生ずる 確率もこれを考慮する必要がある。このような場合を考えた理論解法を求める必要があるが，実測によると単独 に行動するものが約 70\% で，1，2 台以下の8のが $80 \%$ 以上であつで 台の定員 50〜60 名くらい）以下の旅行団体が大多数であることる考觉ると，ここに示した考方方で十分実用供

し得るものと考えられる。な标集団形成を考虑した場合の解法については今後の研究にまちたい。

最後に本研究は昭和 31 年度建設技術研究補助金による研究の一部で方つて, 調查研究に不断の御援助を戴いた 京大教授米谷栄二工博捛よび 研究に非常なる便宜と御支援を賜わつた 大阪市大岡部二郎教授に厚く謝意を表する とともに，資料収集，実態調查には京都市建設局都市計画課の御援助を受けたこと，実測には一部道路公団大阪 支社調査課の御協力並び飞調査資料の整理には京大助手稻見俊明君 (現建設省道路局勤務) 招よび大阪市大技術員 川西 勲君の手をわずらわしたことを記し，心から深謝の意を表する次第である。

\section{参考文献および資料}

1）秉利正光：観光駐車場の将来計画に関与る研究一理論の部一，土木学会論交集第 61 号（昭 34.3）pp.54〜62 表一3 参照.

2) 毛利正光: 同上, 表-4 参照.

3) 毛利正光: 同上, 表-1 参照.

4）毛利正光: 同上，表一2 参照.

5）毛利正光：駐事場計画に関与る基礎理論の研究，土木学会論文集第 38 号（昭 $31.10 ）$ pp.49 53.

6）毛利正光：駐車場計画における車輛の出入量強度の算定法と運営に関する基礎的考察，土木学会論交集第 46 号（昭 32.6） pp.46 51.

7) 毛利正光：バスターミナルの計画運営の理論に関する研究, 土木学会諭文集第 49 号 (昭 32.10 ) pp.9 16

8）毛利正光：交通流の分布に関する統計学的考察, 都市計画学丟誌第 5 巻第 4 号, 通巻第 18 号 1956. No.4 pp. $13 \sim 21$.

9）小河原正已訳：ウイルクス数理統計学, 春日出版社, 1956 年 4 月 pp.328 335.

10) 水野坦他 3 名共著: 統計数值表の使い方, 朝会書店, 昭 $30.1, \mathrm{pp} .73 \sim 77$

11) Frieda S. Swed and C. Eisenhart: Tables for Testing Randomness of Grouping in a Sequence of Alternatives, Annals. of Math. Stat., Vol. XIV(1943) pp.66 87.

12）観光駐車場計画について, 土木学会第 12 回年次学術講演会, 講演集 $\mathrm{pp} .367 \sim 368$ 参照のこと. 